\title{
Heparin-binding proteins from boar seminal plasma affecting the release of prostaglandins and interleukin- 6 by porcine endometrial and cervical cells and bovine endometrial cells
}

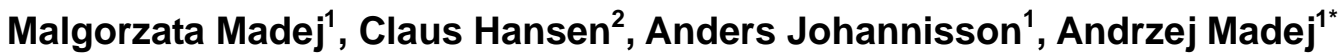 \\ ${ }^{1}$ Department of Anatomy, Physiology and Biochemistry, Swedish University of Agricultural Sciences, Uppsala, Sweden; \\ *Corresponding Author: Andrzej.Madej@,slu.se \\ ${ }^{2}$ Danish Agriculture and Food Council, Copenhagen, Denmark
}

Received 16 May 2013; revised 16 June 2013; accepted 23 June 2013

Copyright (C) 2013 Malgorzata Madej et al. This is an open access article distributed under the Creative Commons Attribution License, which permits unrestricted use, distribution, and reproduction in any medium, provided the original work is properly cited.

\section{ABSTRACT}

The objectives of this study were to explore whether heparin-binding proteins, separated by fast protein liquid chromatography from boar seminal plasma influence the release of prostaglandins $F_{2 a},\left(P F_{2 a}\right), E_{2}\left(P E_{2}\right)$ and interleukin-6 (IL-6) by porcine endometrial and cervical cells and even bovine endometrial cells. In Experiment I, we showed that release of $\mathrm{PGF}_{2 \alpha}$ by endometrial epithelial, endometrial stromal and cervical stromal cells to the medium was inhibited $(p<0.05)$ to $9.0 \%-60.6 \%$ after $24 \mathrm{~h}$ incubation with $125 \mu \mathrm{g}$ of heparin-binding proteins. Tumor necrosis factor $\alpha$ (TNF $\alpha$ ) stimulated release of IL- 6 by endometrial and cervical stromal cells after $24 \mathrm{~h}$ incubation, but in the presence of heparin-binding proteins, this stimulation was attenuated. Release of $\mathrm{PGF}_{2 \alpha}$ by cryopreserved (Experiment II) and primary (Experiment III) cervical stromal cells was significantly inhibited after $3 \mathrm{~h}$ incubation with 66 - $95.4 \mu \mathrm{g}$ of heparinbinding proteins. A significant inhibition of $\mathrm{PGE}_{2}$ release by cryopreserved and primary cervical stromal cells was already achieved after incubation with 16.5 - $23.9 \mu \mathrm{g}$ of heparin-binding proteins. The release of IL- 6 by cryopreserved cells was stimulated after $3 \mathrm{~h}$ incubation with heparinbinding proteins in a dose dependent manner in contrast to the release of IL- 6 by freshly isolated cervical stromal cells. We also found (Experiment IV) that porcine heparin-binding seminal plasma proteins inhibited release of $\mathrm{PGF}_{2 \alpha}$ and stimulated release of IL- 6 by bovine endometrial epithelial cells. In conclusion, a group of heparin-binding proteins separated by fast protein liquid chromatography from boar seminal plasma inhibit PGF PG, $\mathrm{PGE}_{2}$ and stimulate IL-6 release by porcine endometrial and cervical cells, and even by bovine endometrial cells. Thus, these proteins have a similar effect as the entire seminal plasma.

Keywords: Seminal Plasma Proteins; Cell Culture; Porcine; Bovine; Prostaglandins, Interleukin-6

\section{INTRODUCTION}

The potent biological activity of boar seminal plasma to inhibit the release of prostaglandins and to stimulate IL-6 release by porcine endometrial, cervical and bovine endometrial cells has been demonstrated previously [1]. It is well known that prostaglandins $F_{2 \alpha}$ and $E_{2}$, which are of endometrial origin, regulate a number of important physiological functions during the estrous cycle and pregnancy in pigs $[2,3]$. These two prostaglandins are also involved in acute and chronic inflammatory conditions $[4,5]$. Seminal plasma suppresses the migration of polymorphonuclear neutrophil granulocytes (PMNs) into the uterus, decreases PMNs infiltration of the endometrium and enhances the rate of disappearance of uterine inflammation in gilts following breeding [6,7]. Rozeboom, et al. [8] suggested that non-estrogenic factors in seminal plasma may protect spermatozoa from an inflamed uterine environment and consequently a suitable population of viable spermatozoa is able to reach the site of fertilization. Porcine SP does not activate neutrophil chemotaxis, but it might play a different role in the mo- 
dulation of post breeding uterine neutrophil migration compared to spermatozoa in the sow [9]. There are also data that showing that SP induced the inflammatory response of the pig endometrium during mating or artificial insemination (AI) $[10,11]$. Boar SP contains two groups of proteins belonging to the spermadhesin family classified according to their affinity to heparin i.e. heparinbinding and non-heparin-binding [12-16]. RodriguezMartinez, et al. [17] studied the effects of these two groups of proteins on immunological events in the uterine lumen of sows. These authors found that only nonheparin binding spermadhesin PSP-I/PSP-II heterodimer induced migration of PMNs into the uterine cavity of anesthetized and conscious estrous sows, presumably in relation to specific cytokines. The presence of different groups of proteins in boar SP became a key issue for their relationship to fertility [18]. Novak, et al. [19] reported that non-heparin-binding spermadhesin PSP-I abundance was negatively correlated with both in vivo and in vitro fertility. Furthermore, heparin-binding spermadhesin AWN-1 seems to be of importance for future investigation as biological marker of fertility in boars [20]. Our previous observations that AI resulted in an increase in the prostaglandin $\mathrm{F}_{2 \alpha}$ metabolite (PGFM) concentrations in sows, whereas in mated sows no such elevation in PGFM occurred [21-23] led us to the hypothesis that seminal plasma might be responsible for the inhibition of prostaglandins. To test our hypothesis we have done a series of experiments in vitro [1] and demonstrated that boar seminal plasma inhibit prostaglandins (PGFM, $\mathrm{PGF}_{2 \alpha}, \mathrm{PGE}_{2}$ ) release and stimulate IL-6 release by not only porcine endometrial and cervical cells but also by bovine endometrial cells. Thus, the aim of the present study was to investigate the effect of heparin-binding proteins separated by fast protein liquid chromatography (FPLC) from boar SP on the release of $\mathrm{PGF}_{2 \alpha}, \mathrm{PGE}_{2}$ and IL-6 from porcine endometrial and cervical cells and bovine endometrial cells.

\section{MATERIALS AND METHODS}

\subsection{Separation of Proteins from Boar Seminal Plasma}

\subsubsection{Seminal Plasma}

Fresh semen was collected from three Danish Duroc boars and centrifuged at $2000 \mathrm{xg}$ for 20 minutes at $4^{\circ} \mathrm{C}$. The supernatant was centrifuged again; the seminal plasma was pooled, collected to $15-\mathrm{ml}$ tubes with caps and stored at $-20^{\circ} \mathrm{C}$. The total volume of collected seminal plasma was approximately $150 \mathrm{ml}$.

\subsubsection{Affinity Liquid Chromatography of Seminal Plasma}

Seminal plasma proteins were separated on column
HiPrep 16/10 Heparin FF, $20 \mathrm{ml}$ (GE Healthcare BioSciences AB, Uppsala, Sweden) by fast protein liquid chromatography (FPLC) according to Sanz, et al. [12] and Varilova, et al. [24] with some modifications. The column was used directly on ÄKTAdesign ${ }^{\mathrm{TM}}$ systems (Amersham Pharmacia Biotech, Uppsala, Sweden) with UNICORNTM software for data calculations on line. Samples of seminal plasma $(0.5 \mathrm{ml})$ were injected through a valve with $0.5 \mathrm{ml}$ sampling loop. The non-heparin-binding proteins, the first peak (F1) were eluted with $0.02 \mathrm{M}$ Tris- $\mathrm{HCl}$ buffer containing $0.156 \mathrm{M} \mathrm{NaCl}, \mathrm{pH}$ 7.5. The proteins adsorbed on heparin, the second peak (F2), were eluted using $\mathrm{NaCl}$ gradient (within $10 \mathrm{~min}$ ) from $0.156 \mathrm{M}$ to $1.5 \mathrm{M}$ in $0.02 \mathrm{M}$ Tris- $\mathrm{HCl}$ buffer, $\mathrm{pH}$ 7.5. The used flow rate was $1 \mathrm{ml} / \mathrm{min}$. The yield of eluted proteins was evaluated by measurement of absorbance at $280 \mathrm{~nm}$ and $2 \mathrm{ml}$ fractions were collected, lyophilized and stored at $-20^{\circ} \mathrm{C}$.

\subsection{Cell Culture}

\subsubsection{Animals}

In Experiments I-III, the uterus and cervix were collected from gilts slaughtered approximately one week after (gilt no. g 08) and before oestrus (gilt no. g11) in a local abattoir.

\subsubsection{Isolation, Culture and Cryopreservation of Porcine Endometrial and Cervical Cells}

The cells were separated as described earlier [25-28] and recently modified by us [1]. Briefly, uterus and cervix were transported to the laboratory within $60 \mathrm{~min}$ after slaughter in ice-cold phosphate buffered saline (PBS), pH 7.4, saturated with $\mathrm{O}_{2}: \mathrm{CO}_{2}(95 \%: 5 \%)$ and supplemented with antibiotics. After digestion of the uterine tissues with $0.48 \%$ dispase in Hank's incomplete balanced salt solution (HIBSS) with antibiotics, the endometrial epithelial (pUE) cells were centrifuged and washed once with Medium 199. Afterwards, red blood cells lysing buffer (RBCLB) was used to remove erythrocytes. The cells were washed and plated in T-125 flasks for culture at $37^{\circ} \mathrm{C}$ in a humidified atmosphere of 95\% air: $5 \% \mathrm{CO}_{2}$. The culture medium Medium 199 containing $2 \%$ BSA, $10 \%$ foetal bovine serum (FBS), penicillin-streptomycin $(100 \mathrm{IU} / \mathrm{ml}-100 \mu \mathrm{g} / \mathrm{ml})$, gentamycin $(50 \mu \mathrm{g} / \mathrm{ml})$ and amphotericin B $(1 \mu \mathrm{g} / \mathrm{ml})$ was changed every second day until cells were confluent (5 7 days). In order to obtain endometrial stromal (pUS) cells, the remaining tissue was first incubated with $0.25 \%$ trypsin solution for 1 hour at $37^{\circ} \mathrm{C}$, filtered (40- $\mu \mathrm{m}$ nylon sieve), centrifuged and washed with fresh medium. The undigested tissue fragments were further treated with $0.06 \%$ collagenase for $1.5 \mathrm{~h}$ at $37^{\circ} \mathrm{C}$. The cell suspensions obtained after trypsin and collagenase digestions were pooled together, washed, counted and 
plated in T-125 flasks for culture at $37^{\circ} \mathrm{C}$ in humidified atmosphere of $95 \%$ air: $5 \% \mathrm{CO}_{2}$. The culture medium with additives as described for pUE above was changed every second day until the cells were confluent (5 - 7 days).

The cervix was treated with a solution of dispase and pancreatin $(0.48 \%$ and $1.25 \%$, respectively) in HIBSS solution containing antibiotics. After this treatment the remaining tissue samples were incubated with a $0.06 \%$ collagenase, $0.01 \%$ DNase, $0.06 \%$ trypsin in HIBSS solution containing antibiotics to obtain cervical stromal (pCS) cells. The undigested fragments were filtered through $200-\mu \mathrm{m}$ and $40-\mu \mathrm{m}$ pore-size stainless steel and nylon sieves. The pCS cells which passed through the sieves were incubated with the lysing buffer RBCLB, washed and plated in T-125 flasks for culture at $37^{\circ} \mathrm{C}$ in a humidified atmosphere of $95 \%$ air: $5 \% \mathrm{CO}_{2}$. The culture medium Dulbecco's Modified Eagle's Medium Nutrient Mixture F-12 HAM (DMEM-F-12) containing 2\% BSA, 10\% FBS penicillin-streptomycin (100 IU $/ \mathrm{ml} \mathrm{-} 100$ $\mu \mathrm{g} / \mathrm{ml})$, gentamycin $(100 \mu \mathrm{g} / \mathrm{ml})$ and amphotericin B (1 $\mu \mathrm{g} / \mathrm{ml}$ ) was changed every second day until the cells were confluent ( 5 - 7 days). Cryopreservation and thawing of separated cervical stromal cells from gilt no. g08 (pCS-80) was performed as described earlier in our work [1].

The trypan blue exclusion method was applied for counting of the obtained cells. All types of cells were repeatedly controlled for growth and morphology using an inverted microscope (Telaval 31, Carl Zeiss Jena $\mathrm{GmbH}$, Jena, Germany) until they attached and reached confluence. The viability of cells varied between 80 and $90 \%$. The cells cultured in T-125 flasks were removed by treatment with trypsin-EDTA $(0.5 \%-0.2 \%)$ solution, counted and plated on 24-well plates (seeding density 2.5 x $10^{5}$ cells/well) and cultured at $37^{\circ} \mathrm{C}$ in a humidified atmosphere of $95 \%$ air: $5 \% \mathrm{CO}_{2}$ until $80 \%-90 \%$ confluence was reached and experiments could be started. The immunofluorescent staining for specific markers of epithelial cells (cytokeratin) and for stromal cells (vimentin) was applied as described by Blitek and Ziecik [28].

\subsubsection{Bovine Endometrial Epithelial Cells}

Bovine endometrial epithelial cells (commercial name - BEnEpC) derived from healthy bovine uterus includeing cell growth media and subculture reagent kit were purchased from Cell Applications, Inc., San Diego, USA, and cultured according to the recommendations of the manufacturer. These bovine cells shipped at 2 nd passage were propagate to 4th passage and used in Experiment IV.

\subsection{Experiments}

\subsubsection{Experiment I-Effect of SP Proteins on Release of $\mathrm{PGF}_{2 \alpha}$ and IL- 6 by Primary Porcine Cells from Gilt No. g08}

Porcine UE, US and CS cells were cultured for 3 and
$24 \mathrm{~h}$ with heparin-binding F2 proteins (125 $\mu \mathrm{g} /$ well) added to the culture medium. The total incubation volume was $1.0 \mathrm{ml} /$ well. Controls with or without these proteins, AA $(20 \mu \mathrm{g} / \mathrm{ml})$ and TNF $\alpha(1.05 \mathrm{ng} / \mathrm{ml})$ were always in triplicate. The test was repeated 2 or 3 times. The collected media were analysed for the content of $\mathrm{PGF}_{2 \alpha}$ and IL-6.

\subsubsection{Experiment II-Effect of SP Proteins on Release of $\mathrm{PGF}_{2 \alpha}, \mathrm{PGE}_{2}$ and IL- 6 by Cryopreserved and Thawed Porcine Cervical Stromal Cells from Gilt No. g08 (pCS-80)}

Cryopreserved and thawed pCS- 80 cells were cultured for $3 \mathrm{~h}$ with heparin-binding F2 proteins at different concentrations $(0-132 \mu \mathrm{g} / \mathrm{well})$ with $20.0 \mu \mathrm{g} / \mathrm{ml}$ of AA in triplicates. The test was repeated 2 or 3 times. The collected media were analyzed or the content of $\mathrm{PGF}_{2 \alpha}$, $\mathrm{PGE}_{2}$ and IL-6.

\subsubsection{Experiment III-Effect of SP Proteins on Release of $\mathrm{PGF}_{2 \alpha}, \mathrm{PGE}_{2}$ and IL-6 By Primary Porcine Cervical Stromal Cells from Gilt No. g11}

Freshly collected porcine CS cells from gilt no. g11 (pCS-g11) were cultured for $3 \mathrm{~h}$ with heparin-binding F2 proteins at different concentrations $(0-190.8 \mu \mathrm{g} / \mathrm{well})$ with $20.0 \mu \mathrm{g} / \mathrm{ml}$ of AA in 6 replicates. The collected media were analyzed for the content of $\mathrm{PGF}_{2 \alpha}, \mathrm{PGE}_{2}$ and IL-6.

\subsubsection{Experiment IV-Effect of SP Proteins on Release of $\mathrm{PGF}_{2 \alpha}$ and IL- 6 by Bovine Cells (BEnEpC)}

Bovine cells were cultured for 3 and $24 \mathrm{~h}$ with heparin-binding F2 proteins $(125 \mu \mathrm{g} / \mathrm{well})$ added to the culture medium. The total incubation volume was 1.0 $\mathrm{ml} /$ well. Controls with or without these proteins, AA (20 $\mu \mathrm{g} / \mathrm{ml})$ and TNF $\alpha(1.05 \mathrm{ng} / \mathrm{ml})$ were always in triplicate. The test was repeated $2-3$ times. The collected media were analysed for the content of $\mathrm{PGF}_{2 \alpha}$ and IL-6.

When incubation time was complete, the medium from each well in all experiments was collected to tubes containing $10 \mu \mathrm{g} / \mathrm{ml}$ of indomethacin (Fluka, BioChemika, Switzerland) and stored at $-20^{\circ} \mathrm{C}$. The remaining cells on the bottom of the well were then lysed with 0.1 $\mathrm{N} \mathrm{NaOH}(0.5 \mathrm{ml} / \mathrm{well})$, for the total cellular protein determination, and stored at $-20^{\circ} \mathrm{C}$.

\subsection{Biochemical Measurements}

\subsubsection{Prostaglandin $F_{2 \alpha}$ and Prostaglandin $E_{2}$}

The quantitative determination of $\mathrm{PGF}_{2 \alpha}$ and $\mathrm{PGE}_{2}$ in collected media was performed by competitive immunoassay kits, the Assay Designs' Correlate-EIA ${ }^{\mathrm{TM}}$ Pros- 
taglandin $\mathrm{F}_{2 \alpha}$ and the Assay Designs' Correlate-EIA ${ }^{\mathrm{TM}}$ Prostaglandin $E_{2}$, respectively, according to the manufacturer's recommendations (Assay Designs, Inc., Ann Arbor, MI, USA). The intra-assay coefficient of variation for $\mathrm{PGF}_{2 \alpha}$ was below $15 \%$ between 10.0 and $5000 \mathrm{pg} / \mathrm{ml}$. The inter-assay coefficients of variations were $12.5 \%$ at $170.7 \mathrm{pg} / \mathrm{ml}, 7.2 \%$ at $1814 \mathrm{pg} / \mathrm{ml}$ and $10.2 \%$ at 17,573 $\mathrm{pg} / \mathrm{ml}$. The practical limit of the assay sensitivity for 0.05 $\mathrm{ml}$ of medium was approximately $7 \mathrm{pg} / \mathrm{ml}$. The intraassay coefficient of variation for $\mathrm{PGE}_{2}$ was below $10 \%$ between 120.1 and $4689 \mathrm{pg} / \mathrm{ml}$. The inter-assay coefficient of variation was approximately $13 \%$ at 2330.2 $\mathrm{pg} / \mathrm{ml}$. The practical limit of the assay sensitivity for 0.05 $\mathrm{ml}$ of medium was approximately $13 \mathrm{pg} / \mathrm{ml}$.

\subsubsection{Porcine and Bovine IL-6}

Porcine IL-6 (pIL-6) was measured by using solid phase ELISA (R\&D Systems Europe, Ltd. Abingdon, UK) according to the manufacturer's recommendations. No significant relative cross-reactivity was observed with TNF $\alpha$. The inter-assay coefficient of variation was approximately $14.3 \%$ at $251.7 \mathrm{pg} / \mathrm{ml}$. The practical limit of sensitivity for the assay analysing $0.1 \mathrm{ml}$ of medium was approximately $10 \mathrm{pg} / \mathrm{ml}$. Bovine IL-6 (bIL-6) was measured using the xMAPтM technology as applied by Dernfalk, et al. [29] and modified by Madej, et al. [1].

\subsubsection{Protein Analysis}

The total protein content of the cells in each well was determined with the Bio-Rad Protein Microassay kit (Bio-Rad Laboratories, Life Science Group, Sundbyberg, Sweden) according to the manufacturer's recommendations.

All chemicals used in the present study were purchased from Sigma-Aldrich Sweden AB, Stockholm, Sweden, unless otherwise stated.

\subsection{Statistical Analysis}

In Experiment I-II and IV, F2 (125 $\mu \mathrm{g} /$ well), controls with or without AA and TNF $\alpha$ were in triplicate and tests were repeated 2 or 3 times. In Experiment III, F2 (0 $190.8 \mu \mathrm{g} / \mathrm{well})$ and controls with or without AA were either in triplicates or six replicates. Prostaglandin $\mathrm{F}_{2 \alpha}, \mathrm{E}_{2}$ and IL- 6 output data in 3 and $24 \mathrm{~h}$ post-treatment media were expressed per $\mu \mathrm{g}$ of cellular proteins. Data were log transformed and analysed with a one-way ANOVA followed by Newman-Keuls Multiple Comparison Test for multiple groups to compare the differences between treatment groups according to the GraphPad Prism version 5.02 for Windows (GraphPad Software, San Diego, CA, USA). Data are presented as a mean \pm SEM.

\section{RESULTS}

\subsection{Affinity Liquid Chromatography}

Figure 1 depicts a typical chromatogram of boar SP using an affinity stationary phase with immobilized heparin on the column HiPrep 16/10 Heparin FF. Based on the total protein content $(16.4 \mathrm{mg} / \mathrm{ml})$ and recovery from FPLC (63.9\%) we estimated that each $\mathrm{ml}$ of this pooled seminal plasma consists of $13.0 \mathrm{mg}$ non-heparinbinding proteins (F1) and $3.4 \mathrm{mg}$ heparin-binding proteins (F2). In total, $196 \mathrm{mg}$ of F1 and $54 \mathrm{mg}$ of F2 was obtained.

\subsection{Experiment I}

The basal concentrations of $\mathrm{PGF}_{2 \alpha}$ in the collected control media from the pUE cells after 3 and $24 \mathrm{~h}$ incubation without AA were $1.9 \pm 0.1$ and $3.1 \pm 0.2 \mathrm{pg} / \mu \mathrm{g}$ protein, respectively (Figures 2(a),(b)). Addition of AA to the medium in the control wells did not increase $\mathrm{PGF}_{2 \alpha}$ release after $3 \mathrm{~h}$ and $24 \mathrm{~h}$. Release of $\mathrm{PGF}_{2 \alpha}$ to the medium with and without AA was inhibited $(\mathrm{p}<0.05)$ to 41.2 and $60.6 \%$, respectively, only after $24 \mathrm{~h}$ incubation with $125 \mu \mathrm{g}$ of F2 (Figure 2(b)).

The basal concentrations of $\mathrm{PGF}_{2 \alpha}$ in the collected control media from the pUS cells after 3 and $24 \mathrm{~h}$ incubation without AA were $5.7 \pm 0.8$ and $14.8 \pm 2.5 \mathrm{pg} / \mu \mathrm{g}$ protein, respectively (Figures 2(c),(d)). Addition of AA to the medium in the control wells increased $(\mathrm{p}<0.05)$ $\mathrm{PGF}_{2 \alpha}$ release after $3 \mathrm{~h}$ and $24 \mathrm{~h}$. Release of $\mathrm{PGF}_{2 \alpha}$ to the medium with and without AA by pUS was inhibited $(\mathrm{p}<$ 0.05 ) to $18 \%-38 \%$ after 3 and $24 \mathrm{~h}$ incubation with 125 $\mu \mathrm{g}$ of F2 (Figures 2(c),(d)).

The basal concentrations of $\mathrm{PGF}_{2 \alpha}$ in the collected control media from the pCS cells after 3 and $24 \mathrm{~h}$ incubation without AA were $3.1 \pm 0.2$ and $12.6 \pm 1.2 \mathrm{pg} / \mu \mathrm{g}$ protein, respectively (Figures 2(e),(f)). Addition of AA to the medium in the control wells increased $(p<0.05)$

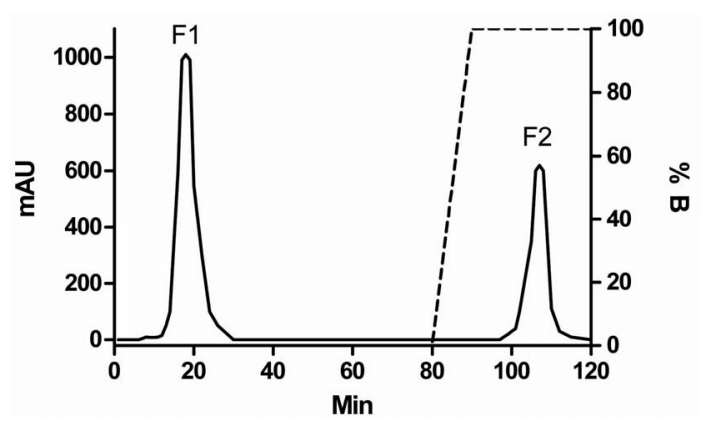

Figure 1. Schematic FPLC profile after separation of $0.5 \mathrm{ml}$ boar (SP). Elution buffer: $0.02 \mathrm{M}$ Tris- $\mathrm{HCl}$ buffer, $\mathrm{pH} 7.5$ with $0.156 \mathrm{M} \mathrm{NaCl}$ (F1-non-heparin-binding proteins) and $\mathrm{NaCL}$ gradient $0.156-1.5 \mathrm{M}$ in $0.02 \mathrm{M}$ Tris-HCL buffer $\mathrm{pH} 7.5$ (F2 heparin-binding proteins). Volume of collected fractions was 2 $\mathrm{ml}$ and flow rate was $1 \mathrm{ml} / \mathrm{min}$. Absorbance in milli-absorbance units (mAU) at $280 \mathrm{~nm}$. 

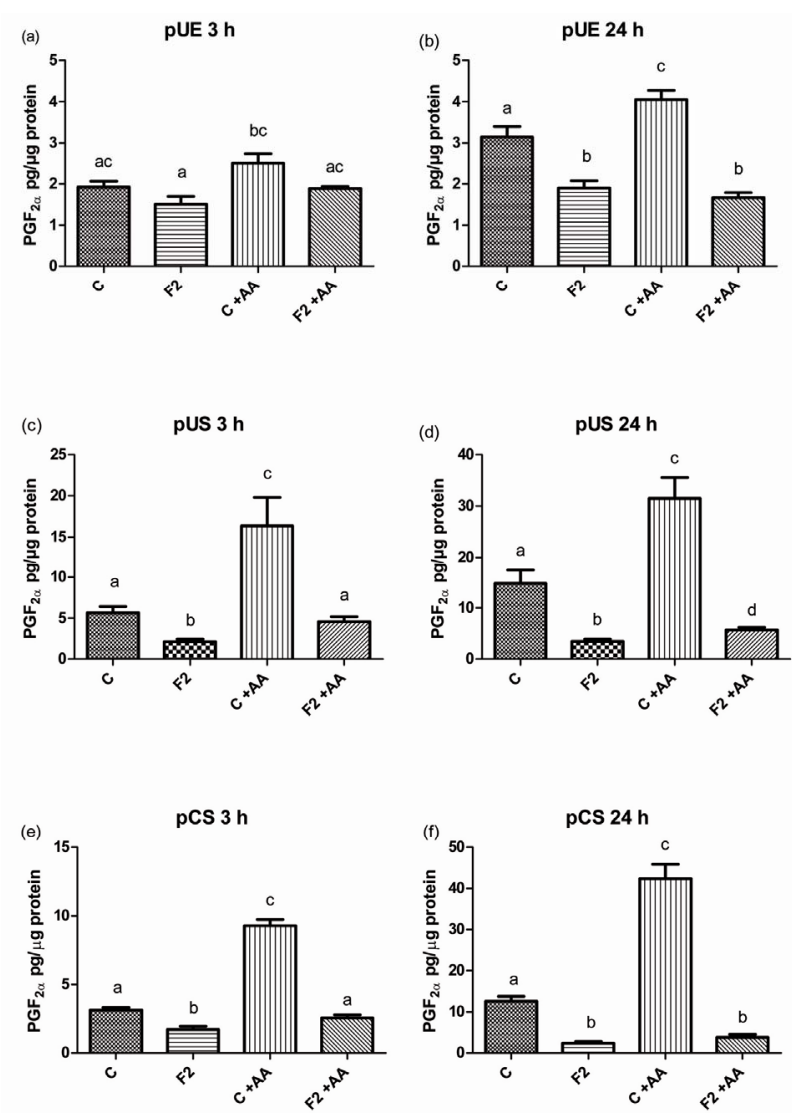

Figure 2. The effect of heparin-binding (F2) seminal plasma proteins on the release of $\mathrm{PGF}_{2 \alpha}$ by porcine endometrial epithelial (pUE) (a) porcine endometrial stromal cells (pUS); (b) porcine cervical stromal (pCS); (c) after $3 \mathrm{~h} \mathrm{(a,} \mathrm{c,} \mathrm{e)} \mathrm{and} 24 \mathrm{~h} \mathrm{(b,}$ $\mathrm{d}, \mathrm{f}$ ) incubation compared with controls (C). The medium was with and without arachinonic acid (AA). Bars with different superscripts within each diagram are different $(\mathrm{P}<0.05)$.

$\mathrm{PGF}_{2 \alpha}$ release after $3 \mathrm{~h}$ and $24 \mathrm{~h}$. Release of $\mathrm{PGF}_{2 \alpha}$ to the medium was inhibited $(\mathrm{p}<0.05)$ to $9 \%-54 \%$, both with and without AA, at 3 and $24 \mathrm{~h}$ incubation with $125 \mu \mathrm{g}$ of F2 (Figures 2(e),(f)). Addition of TNF $\alpha$ to the medium in wells with all types of cells did not affect inhibitory activity of F2 (data not shown).

Addition of TNF $\alpha$ to the control wells with pUS and $\mathrm{pCS}$ resulted in a dramatic increase $(\mathrm{p}<0.05)$ in the release of pIL-6 after $24 \mathrm{~h}$ incubation (Figures 3(a),(b)). Addition of F2 together with TNF $\alpha$ to the medium with pUS and pCS inhibited $(\mathrm{p}<0.05)$ release of $\mathrm{pIL}-6$, from $0.538 \pm 0.052$ and $0.206 \pm 0.026 \mathrm{pg} / \mu \mathrm{g}$ protein, respectively to $0.048 \pm 0.006$ and $0.028 \pm 0.006 \mathrm{pg} / \mu \mathrm{g}$ protein, respectively after $24 \mathrm{~h}$ incubation.

\subsection{Experiment II}

The basal concentrations of $\mathrm{PGF}_{2 \alpha}, \mathrm{PGE}_{2}$ and IL-6 in the collected media after $3 \mathrm{~h}$ incubation of pCS- 80 were $15.2 \pm 0.7,406.5 \pm 71.8$ and $0 \mathrm{pg} / \mu \mathrm{g}$ protein, respectively (Figures 4(a)-(c)). Incubation of pCS-80 cells
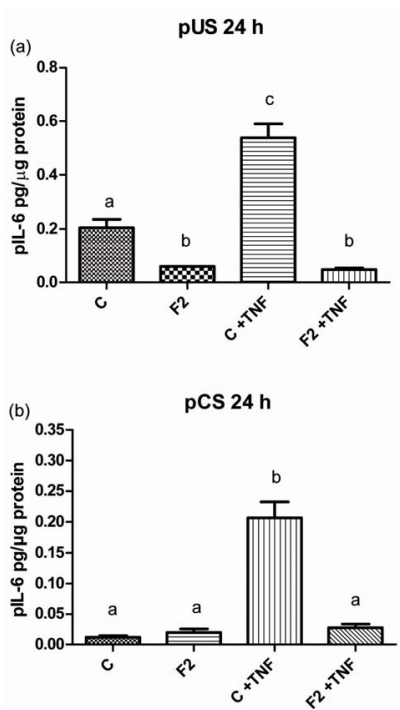

Figure 3. The effect of heparin-binding (F2) seminal plasma proteins on the release of pIL-6 by porcine endometrial stromal (pUS) (a) and porcine cervical stromal (pCS); (b) cells after 24 $\mathrm{h}$ incubation compared with controls $(\mathrm{C})$. The medium was in the presence and absence of tumour necrosis factor (TNF $\alpha$ ). Bars with different superscripts within each diagram are different $(\mathrm{P}<0.05)$.

with different concentrations of F2 proteins resulted in the inhibition of prostaglandins and stimulation of IL- 6 release. Release of $\mathrm{PGF}_{2 \alpha}$ was inhibited $(\mathrm{p}<0.05)$ to $55.2 \%$ after incubation with $66 \mu \mathrm{g}$ of F2 (Figure 4(a)). Inhibition $(\mathrm{p}<0.05)$ of $\mathrm{PGE}_{2}$ release to $16.0 \%$ was already achieved after incubation with the lowest dose 16.5 $\mu \mathrm{g}$ of F2 (Figure 4(b)). Addition of increasing doses of F2 from 16.5 to $132 \mu \mathrm{g}$ to the medium increased ( $\mathrm{p}<$ 0.05 ) release of IL- 6 from $0.2 \pm 0.0$ to $1.0 \pm 0.06 \mathrm{pg} / \mu \mathrm{g}$ protein (Figure 4(c)).

\subsection{Experiment III}

The basal concentrations of $\mathrm{PGF}_{2 \alpha}, \mathrm{PGE}_{2}$ and IL-6 in the collected media after $3 \mathrm{~h}$ incubation of primary pCS-g 11 cells were $24.6 \pm 3.8,361.9 \pm 51.8$ and $0 \mathrm{pg} / \mu \mathrm{g}$ protein, respectively (Figures 4(d)-(f)). Incubation of pCS-g11 cells with different concentrations of $\mathrm{F} 2$ proteins resulted in inhibition of prostaglandins and stimulation of IL-6 release. Release of $\mathrm{PGF}_{2 \alpha}$ was inhibited $(\mathrm{p}<0.05)$ to $38.4 \%$ after incubation with $95.4 \mu \mathrm{g}$ of F2 (Figure 4(d)). Inhibition $(\mathrm{p}<0.05)$ of $\mathrm{PGE}_{2}$ release to $41.6 \%$ was already achieved after incubation with the lowest dose 23.9 $\mu \mathrm{g}$ of F2 (Figure 4(e)). Incubation of pCS with different doses of F2 did not result in release of IL-6 in a dose dependent manner (Figure 4(f)).

Overall, heparin-binding SP proteins had no negative effect on the cellular protein content of porcine cells in all experiments compared to the controls e.g. protein content was $85.8 \pm 0.7 \mu \mathrm{g}$ in control wells, $91.8 \pm 0.7 \mu \mathrm{g}$ 

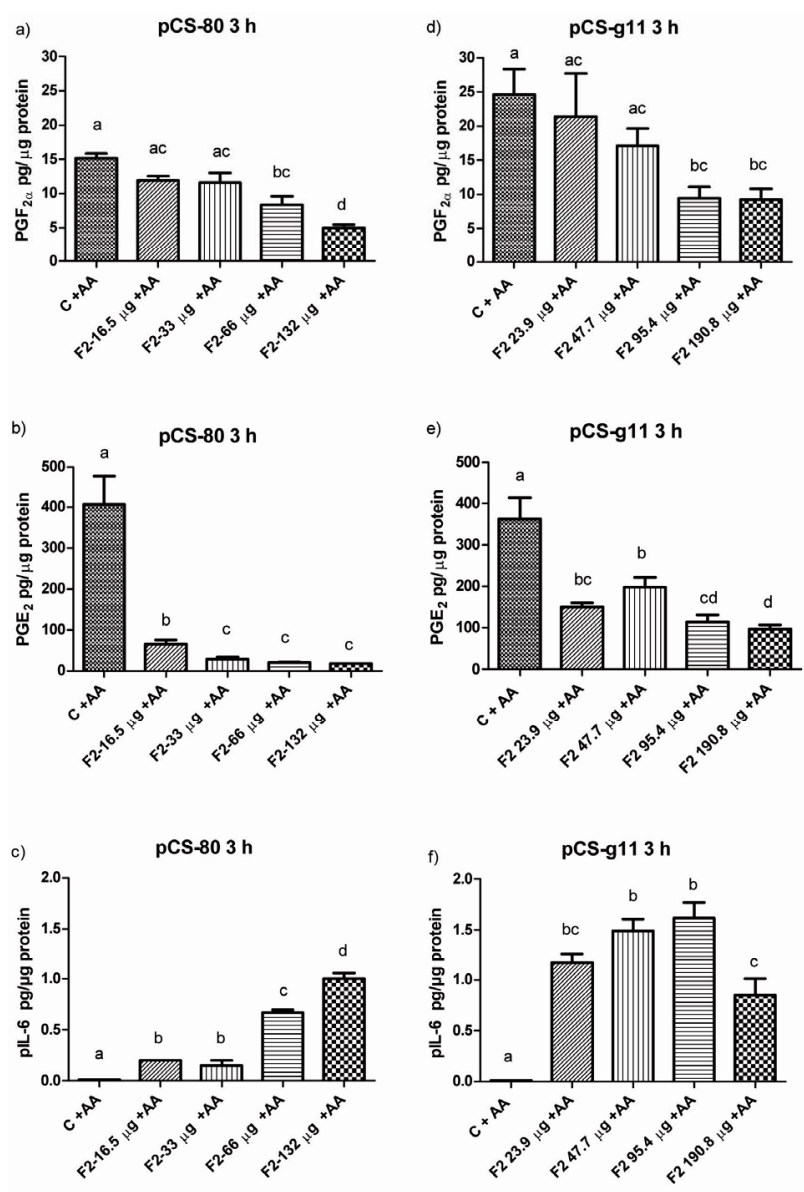

Figure 4. The effect of different doses of heparin-binding (F2) seminal plasma proteins on the release of $\mathrm{PGF}_{2 \alpha}, \mathrm{PGE}_{2}$ and pIL- 6 by cryopreserved (a, b, c- $-\mathrm{pCS}-80)$ and freshly collected porcine cervical stromal cells $(\mathrm{d}, \mathrm{e}, \mathrm{f}-\mathrm{pCSg} 11)$ after $3 \mathrm{~h}$ incubation compared with controls (C). The medium was with arachinonic acid (AA). Bars with different superscripts within each diagram are different $(\mathrm{P}<0.05)$.

in wells with $16.5 \mu \mathrm{g}$ of F2 and $90.6 \pm 0.5$ in wells with $132 \mu \mathrm{g}$ of $\mathrm{F} 2$ and after $3 \mathrm{~h}$ incubation $(\mathrm{P}>0.05)$ (data concern Figures 4(a)-(c)).

\subsection{Experiment IV}

The basal concentrations of $\mathrm{PGF}_{2 \alpha}$ in the collected control media from the BEnEpC cells after 3 and $24 \mathrm{~h}$ incubation without $\mathrm{AA}$ were $3.7 \pm 0.2$ and $1.7 \pm 0.2$ $\mathrm{pg} / \mu \mathrm{g}$ protein, respectively (Figure 5(a)). Addition of AA to the medium in the control wells did not increase $\mathrm{PGF}_{2 \alpha}$ release after $3 \mathrm{~h}$ but did increase $(\mathrm{p}<0.05)$ it after $24 \mathrm{~h}$. Release of $\mathrm{PGF}_{2 \alpha}$ to the medium with and without AA was inhibited $(\mathrm{p}<0.05)$ to about $57 \%$ after $3 \mathrm{~h}$ incubation with $125 \mu \mathrm{g}$ of F2 (proteins binding to heparin) (Figure 5(a)). Almost the same inhibition, 60\% was achieved after $24 \mathrm{~h}$ incubation without the presence of AA. In the presence of AA, proteins from F2 did not inhibit release of $\mathrm{PGF}_{2 \alpha}$ after $24 \mathrm{~h}$ incubation (Figure
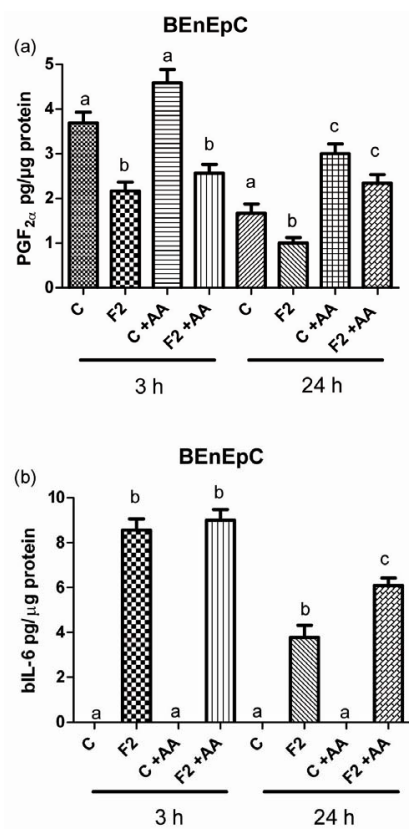

Figure 5. The effect of heparin-binding (F2) seminal plasma proteins on the release of $\mathrm{PGF}_{2 \alpha}$ (a) and bIL-6; (b) by bovine endometrial epithelial cells (BEnEpC) after 3 and $24 \mathrm{~h}$ incubation compared with controls $(\mathrm{C})$. The medium was with $(\mathrm{C}$ + AA) and without (C) arachinonic acid (AA). Bars with different superscripts within an incubation time are different $(\mathrm{P}<$ $0.05)$.

5(a)). Addition of TNF $\alpha$ to the medium has prevented the inhibition of $\mathrm{PGF}_{2 \alpha}$ release after incubation with 125 $\mu \mathrm{g}$ of F2 (data not shown).

The concentrations of bIL-6 in the control media were below the detection limit. Release of bIL-6 by the $\mathrm{BEnEpC}$, cells had increased $(\mathrm{P}<0.05)$, from 0 to 8.6 $9.0 \pm 0.5 \mathrm{pg} / \mu \mathrm{g}$ protein after $3 \mathrm{~h}$ incubation with $125 \mu \mathrm{g}$ of F2 despite the presence or absence of AA. After $24 \mathrm{~h}$ this increase was lower $(\mathrm{P}<0.05)$ but AA strengthened the stimulatory effect of F2 (Figure 5(b)). There was also no difference in the cellular protein content of wells with and without F2 within the incubation time. Protein content was $282.5 \pm 11.1 \mu \mathrm{g}$ in control wells and $294.7 \pm$ $11.9 \mu \mathrm{g}$ in wells with $\mathrm{F} 2$ after $3 \mathrm{~h}$ incubation $(\mathrm{P}>0.05)$. After $24 \mathrm{~h}$ incubation, cellular protein content with and without F2 was $551.1 \pm 54.9 \mu \mathrm{g}$ and $605.1 \pm 57.8 \mu \mathrm{g}(\mathrm{P}$ $>0.05)$, respectively.

\section{DISCUSSION}

The application of FPLC system and column prepacked with porcine heparin-Sepharose gave us possibility to separate non-heparin and heparin-binding proteins from boar SP in an efficient and reproducible manner. The FPLC separation always resulted in two peaks in agreement with the previous findings [12,24]. Varilova, et al. [24] reported that boar SP contained about 35\% of heparin-binding proteins but did not specify breed of the 
pig tested. The pooled SP from our three Danish Duroc boars contained about $21 \%$ of heparin-binding and $79 \%$ non-heparin binding proteins. The semen of these boars was approved according to the Artificial Insemination (AI) Guidelines for the Danish DanBred AI-stations. The following proteins are belong to the heparin-binding group: 1) spermadhesins of families [the Alanine-Glutamine-Asparagine and the Alanine-Tryptophan-Asparagine proteins] (AQN and AWN, respectively); and 2) sperm protein surface $\mathrm{pB} 1$ homolog to [the Aspartic acidGlutamine-Histidine protein] (DQH) [12-14,16,30,31]. The non-heparin-binding group consists of mainly spermadhesin, the Porcine Seminal Plasma proteins (PSP-I and PSP-II) $[32,33]$.

In the present study, we demonstrated that heparinbinding proteins (F2) separated on FPLC from boar SP have the ability to inhibit the release of $\mathrm{PGF}_{2 \alpha}$ by porcine endometrial and cervical cells. The F2 proteins had also the ability to inhibit the release of $\mathrm{PGE}_{2}$ by porcine cervical stromal cells. This is in agreement with our previous findings on the ability of the entire boar SP to inhibit prostaglandins release by porcine endometrial and cervical cells [1]. In addition, we have now evidence suggesting that the difference in PGFM pattern in the peripheral blood seen between artificially inseminated and mated sows [21-23] was probably due to heaprin-binding proteins inhibition of prostaglandins release in the uterus and cervix.

$\mathrm{PGF}_{2 \alpha}$ formed in vivo from arachidonic acid in the endometrium is well known as a regulator of corpora luteal function, uterine contractility, ovulation, embryo development and parturition in pigs [2,3]. Biological activity of $\mathrm{PGF}_{2 \alpha}$ was recently extended to pathophysiological processes, such as acute and chronic inflammation, cardiovascular and rheumatic diseases [4,34]. This means that $\mathrm{PGF}_{2 \alpha}$ may be considered as a complementtary agent to $\mathrm{PGE}_{2}$ which is the most pleiotropic prostanoid that controls inflammation, fever, pain and cancer through its receptors EP1 to EP4. The effectiveness of aspirin and non-steroidal anti-inflammatory drugs (NSAIDs) acting as COX-inhibitors indicates the importance of $\mathrm{PGF}_{2 \alpha}$ and $\mathrm{PGE}_{2}$ during the development of inflammation-associated processes [4,5]. Serhan, et al. [35] concluded that indicators of an ongoing inflammatory process are also enzymes involved in the arachidonic acid metabolism, cyclooxygenase-2 (COX-2) and arachidonate 5-lipooxygenase (ALOX-5). The expression of COX-2 mRNA was significantly increased in the endometrium of gilts inseminated with semen extended in AndrohepTM compared to gilts inseminated with SP [36]. These findings may indicate the presence of immune-stimulating constituents in the artificial semen extender and the lack of such in SP. Therefore, Taylor, et al. [36] suggested the existence of immune suppressing substances in porcine SP and this hypothesis is recently supported by findings of Jiwakanon, et al. [7]. Quite similar concept about the protection of spermatozoa from harmful influences was offered by Aloe, et al. [37] who have shown the ability of bovine SP and vesicular gland fluid (VGF) to block IL-8 stimulated PMN transmigration in vitro and to reduce the incidence of cell- damageing reactive oxygen species. Given the recent findings of non-heparin-binding SP proteins' that induce migration of PMNs into the uterine cavity in sows [17] and their negative correlation with fertility [19] it is conceivable that heparin-binding SP proteins biological activity to inhibit the release of prostaglandins, found in the present study, is of importance for reproductive processes. In fact, our preliminary study demonstrated that low content of heparin-binding proteins in SP was related to reduced fertility of boars in term of litter size born [38]. Very recently, it was reported that the $\mathrm{PGE}_{2}: \mathrm{PGF}_{2 \alpha}$ ratio in uterine luminal flushings was significantly lower in SP-treated gilts than in controls on day 1 after intrauterine infusion [39]. When calculating the $\mathrm{PGE}_{2}: \mathrm{PGF}_{2 \alpha}$ ratio from our present study we found that this ratio is signifycantly decreased after incubation with different concentrations of heparin-binding proteins.

Supplementation of porcine semen extender containing boar SP may reduce both chemotactic and phagocytotic activities of porcine PMNs for sperm following AI [40]. However, identification of the SP factors involved in the development of maternal immune tolerance to the conceptus requires further studies [41].

Interleukin-6 is recognized to be a multifunctional cytokine that regulates immune response and induces acute phase response. IL-6 has a very important role in regulating the balance between IL-17-producing T helper 17 cells (Th17) and regulatory $\mathrm{T}$ cells (Treg) but overproduction of IL-6 may lead to imbalances in Th17/Treg and subsequently to inflammatory processes [42]. Human SP stimulated mRNA expression of IL- 6 in endometrial epithelial cells without any effect on TNF $\alpha$ expression [43] and induced an increase of IL- 6 and IL- 8 secretion by peripheral mononuclear blood cells whereas the secretion of TNF $\alpha$ was reduced [44]. In gilts, immunohistochemical labelling for IL- 6 in the endometrium was slightly higher $35-40 \mathrm{~h}$ than $5-6 \mathrm{~h}$ after insemination [7]. The gene responsible for the IL-6 receptor was up-regulated in the endometrium of pregnant compared to non-pregnant sows [45]. In the present study, we demonstrated that heparin-binding proteins from boar SP stimulate IL-6 release by porcine cervical stromal cells after $3 \mathrm{~h}$ incubation. The magnitude of IL-6 release stimulated by heparin-binding proteins was much higher than observed after stimulation after stimulation with 5\% seminal plasma [1].

Attenuation of porcine IL-6 release by heparin-binding 
proteins after stimulation of porcine endometrial and cervical stromal cells with TNF $\alpha$ during $24 \mathrm{~h}$ resembles the effect of entire SP described by Madej, et al. [1]. The stimulatory effect of TNF $\alpha$ on IL-6 release in the present work is in agreement with the findings of [46] studying production of IL- 6 by cultured human endometrial stromal cells for $24 \mathrm{~h}$ in the presence of TNF $\alpha$. It might be possible that $\mathrm{TNF} \alpha$ stimulates overproduction of IL-6, which may lead to imbalances between Th17 and regulatory $\mathrm{T}$ cells [42]. Thus, it can therefore be speculated that either heparin-binding proteins or entire SP inhibit overproduction of IL-6 by porcine endometrial and cervical cells, probably to avoid inflammatory response.

We also demonstrated that porcine F2 heparin-binding proteins decreased $\mathrm{PGF}_{2 \alpha}$ release by bovine endometrial epithelial cells. This is in agreement with our previous findings on the ability of the entire boar SP to inhibit prostaglandins release by bovine endometrial epithelial cells [1]. It is interesting that cortisol decreased basal production of $\mathrm{PGF}_{2 \mathrm{a}}$ from bovine endometrial stromal cells in a dose dependent manner without effecting $\mathrm{PGE}_{2}$ production [47]. A possible mechanism by which glucocorticoids suppress prostaglandin synthesis is by inhibiting the release of the prostaglandins precursor, arachidonic acid, catalyzed by phospholipase A2 (PLA2) [4]. The question of whether heparin-binding proteins from boar SP are inhibiting prostaglandins synthesis in a similar manner to cortisol or through the COX-1/COX2 pathway is open and needs to be elucidated in the future.

Questions can be raised whether it is possible to explain a similar effect of boar heparin-binding proteins and also the entire boar SP on bovine and porcine endometrial cells in terms of $\mathrm{PGF}_{2 \alpha}$ inhibition and IL-6 stimulation. Experimental observations have shown that proteins with $50 \%$ - 98\% sequence identity with boar spemadhesins are present in bull and stallion seminal plasma $[48,49]$. Reference [50] was first to demonstrate that not only porcine SP protein $\mathrm{pB} 1$ could potentiate the capacitation of boar epididymal sperm but also the homologous bovine SP protein BSP-A1/-A2. Furthermore, boar seminal plasma significantly reduced chemototactic and phagocytotic activities of bovine PMNs for bull sperm [40].

\section{CONCLUSION}

A group of heparin-binding proteins separated by FPLC from boar SP inhibit $\mathrm{PGF}_{2 \alpha}, \mathrm{PGE}_{2}$ and stimulate IL-6 release by porcine endometrial, cervical and bovine endometrial cells. Thus, these proteins have a similar effect as the entire SP. This biological activity of porcine heparin-binding seminal plasma proteins found in the present study is in agreement with previous suggestions about the existence of immune modulating substances in porcine SP. Overall, heparin-binding SP proteins had no negative effect on the cellular protein content of porcine and bovine cells in all experiments.

\section{ACKNOWLEDGEMENTS}

This research was financially supported by Danish Agriculture and Food Council, Denmark and EU (Grant no. 3663-D-10-00461). Professor Anders Andrén, Department of Food Science and Professor Jan-Erik Lindberg and Associate Professor Torbjörn Lundh, Department of Animal Nutrition and Management are acknowledged for the facilities they have placed in for our disposal. We thank also Mr. Sören Johansson for help with collection of material.

\section{REFERENCES}

[1] Madej, M., Norrby, M., Madsen, M.T., Johannisson, A., Hansen, C. and Madej, A. (2012) The effect of boar seminal plasma on the release of prostaglandins and interleukin- 6 by porcine endometrial and cervical cells and bovine endometrial cells. Reproduction in Domestic Animals, 47, 113-124. doi:10.1111/j.1439-0531.2011.01809.x

[2] De Rensis, F., Saleri, R., Tummaruk, P., Techakumphu, M. and Kirkwood, R.N. (2011) Prostaglandin $F_{2 \alpha}$ and control of reproduction in female swine: A review. Theriogenology, 77, 1-11. doi:10.1016/j.theriogenology.2011.07.035

[3] Ziecik, A.J., Waclawik, A., Kaczmarek, M.M., Blitek, A., Jalali, B.M. and Andronowska, A. (2011) Mechanisms for the establishment of pregnancy in the pig. Reproduction in Domestic Animals, 46, 31-41. doi:10.1007/s10059-010-0157-1

[4] Basu, S. (2010) Bioactive eicosanoids: Role of prostaglandin $\mathrm{F}_{2 \alpha}$ and $\mathrm{F}_{2}$-isoprostanes in inflammation and oxidative stress related pathology. Molecules and Cells, 30, 383-391. doi:10.1538/expanim.60.7

[5] Murakami, M. (2011) Lipid mediators in life science. Experimental Animals, 60, 7-20.

[6] Rozeboom, K.J., Troedsson, M.H., Molitor, T.W. and Crabo, B.G. (1999) The effect of spermatozoa and seminal plasma on leukocyte migration into the uterus of gilts. Journal of Animal Science, 77, 2201-2206.

[7] Jiwakanon, J., Persson, E., Berg, M. and Dalin, A.M. (2011) Influence of seminal plasma, spermatozoa and semen extender on cytokine expression in the porcine endometrium after insemination. Animal Reproduction Science, 123, 210-220.

doi:10.1016/j.anireprosci.2010.11.016

[8] Rozeboom, K.J., Troedsson, M.H.T., Hodson, H.H., Shurson, G.C. and Crabo, B.G. (2000) The importance of seminal plasma on the fertility of subsequent artificial inseminations in swine. Journal of Animal Science, 78, 443-448.

[9] Rozeboom, K.J., Troedsson, M.H., Rocha, G.R. and Crabo, B.G. (2001) The chemotactic properties of porcine seminal components toward neutrophils in vitro. Journal 
of Animal Science, 79, 996-1002.

[10] Bischof, R.J., Lee, C.S., Brandon, M.R. and Meeusen, E. (1994) Inflammatory response in the pig uterus induced by seminal plasma. Journal of Reproductive Immunology, 26, 131-146. doi:10.1016/0165-0378(94)90036-1

[11] O’Leary, S., Jasper, M.J., Warnes, G.M., Armstrong, D.T. and Robertson, S.A. (2004) Seminal plasma regulates endometrial cytokine expression, leukocyte recruitment and embryo development in the pig. Reproduction, 128, 237-247. doi:10.1530/rep.1.00160

[12] Sanz, L., Calvete, J.J., Mann, K., Gabius, H.J. and Topferpetersen, E. (1993) Isolation and biochemicalcharacterization of heparin-binding proteins from boar seminal plasma - a dual role for spermadhesins in fertilization. Molecular Reproduction and Development, 35, 37-43. doi:10.1002/mrd.1080350107

[13] Jonakova, V., Kraus, M., Veselsky, L., Cechova, D., Bezouska, K. and Ticha, M. (1998) Spermadhesins of the AQN and AWN families, DQH sperm surface protein and HNK protein in the heparin-binding fraction of boar seminal plasma. Journal of Reproduction and Fertility, 114, 25-34.

[14] Manaskova, P., Meszarosova, A., Liberda, J., Voburka, Z., Ticha, M. and Jonakova, V. (1999) Aggregated forms of heparin-binding and non-heparin-binding proteins of boar seminal plasma and their binding properties. Folia Biologica, 45, 193-201.

[15] Caballero, I., Vazquez, J.M., Rodriguez-Martinez, H., Gil, M.A., Calvete, J.J., Sanz, L., Garcia, E.M., Roca, J. and Martinez, E.A. (2005) Influence of seminal plasma PSP-I/PSP-II spermadhesin on pig gamete interaction. Zygote, 13, 11-16. doi:10.1017/S0967199405003072

[16] Caballero, I., Vazquez, J.M., García, E.M., Parrilla, I., Roca, J., Calvete, J.J., Sanz, L. and Martínez, E.A. (2008) Major proteins of boar seminal plasma as a tool for biotechnological preservation of spermatozoa. Theriogenology, 70, 1352-1355. doi:10.1016/j.theriogenology.2008.07.013

[17] Rodriguez-Martinez, H., Saravia, F., Wallgren, M., Martinez, E.A., Sanz, L., Roca, J., Vazquez, J.M. and Calvete, J.J. (2010) Spermadhesin PSP-I/PSP-II heterodimer induces migration of polymorphonuclear neutrophils into the uterine cavity of the sow. Journal of Reproductive Immunology, 84, 57-65. doi:10.1016/j.jri.2009.10.007

[18] Rodríguez-Martínez, H., Kvist, U., Ernerudh, J., Sanz, L. and Calvete, J.J. (2011) Seminal Plasma Proteins: What Role Do They Play? American Journal of Reproductive Immunology, 66, 11-22. doi:10.1111/j.1600-0897.2011.01033.x

[19] Novak, S., Ruiz-Sanchez, A., Dixon, W. T., Foxcroft, G.R. and Dyck, M.K. (2010) Seminal plasma proteins as potential markers of relative fertility in boars. Journal of Andrology, 31, 188-200. doi:10.2164/jandrol.109.007583

[20] Dyck, M.K., Foxcroft, G.R., Novak, S., Ruiz-Sanchez, A., Patterson, J. and Dixon, W.T. (2011) Biological markers of boar fertility. Reproduction in Domestic Animals, 46, 55-58. doi:10.1111/j.1439-0531.2011.01837.x
[21] Madsen, M.T., Larsen, M., Mathiasen, J., Kindahl, H., Einarsson, S. and Madej, A. (2002) Plasma levels of oxytocin and $\mathrm{PGF}_{2 \alpha}$ metabolite during $\mathrm{AI}$ and mating in multiparous sows. Reproduction in Domestic Animals, 37, 242.

[22] Madej, A., Lang, A., Brandt, Y., Kindahl, H., Madsen, M. T. and Einarsson, S. (2005) Factors regulating ovarian function in pigs. Domestic Animal Endocrinology, 29, 347-361. doi:10.1016/j.domaniend.2005.02.030

[23] Norrby, M., Madsen, M.T., Alexandersen, C.B., Kindahl, H. and Madej, A. (2007) Plasma concentrations of cortisol and $\mathrm{PGF}_{2 \alpha}$ metabolite in Danish sows during mating, and intrauterine and conventional insemination. Acta Veterinaria Scandinavica, 49, 36. doi:10.1186/1751-0147-49-36

[24] Varilova, T., Semenkova, H., Horak, P., Madera, M., Pacakova, V., Ticha, M. and Stulik, K. (2006) Affinity liquid chromatography and capillary electrophoresis of seminal plasma proteins. Journal of Separation Science, 29, 1110-1115. doi:10.1002/jssc.200500405

[25] Zhang, Z., Paria, B.C. and Davis, D.L. (1991) Pig endometrial cells in primary culture: Morphology, secretion of prostaglandins and proteins, and effects of pregnancy. Journal of Animal Science, 69, 3005-3015.

[26] Uzumcu, M., Braileanu, G.T., Carnahan, K.G., Ludwig, T.E. and Mirando, M.A. (1998) Oxytocin-stimulated phosphoinositide hydrolysis and prostaglandin $\mathrm{f}$ secretion by luminal epithelial, glandular epithelial, and stromal cells from pig endometrium. I. Response of cyclic pigs on day 16 postestrus. Biology of Reproduction, 59, 1259-1265. doi:10.1095/biolreprod59.5.1259

[27] Guseva, N.V., Knight, S.T., Whittimore, J.D. and Wyrick, P.B. (2003) Primary cultures of female swine genital epithelial cells in vitro: A new approach for the study of hormonal modulation of chlamydia infection. Infection and Immunity, 71, 4700-4710. doi:10.1128/IAI.71.8.4700-4710.2003

[28] Blitek, A. and Ziecik, A.J. (2004) Prostaglandins F-2 alpha and E-2 secretion by porcine epithelial and stromal endometrial cells on different days of the oestrous cycle. Reproduction in Domestic Animals, 39, 340-346. doi:10.1111/j.1439-0531.2004.00523.x

[29] Dernfalk, J., Persson Waller, K. and Johannisson, A. (2007) The xMAP (TM) technique can be used for detection of the inflammatory cytokines IL-1 beta, IL-6 and TNF-alpha bovine samples. Veterinary Immunology and Immunopathology, 118, 40-49. doi:10.1016/j.vetimm.2007.04.004

[30] Calvete, J. J., Raida, M., Gentzel, M., Urbanke, C., Sanz, L. and Töpfer-Petersen, E. (1997) Isolation and characterization of heparin- and phosphorylcholine-binding proteins of boar and stallion seminal plasma. Primary structure of porcine pB1. FEBS Letters, 407, 201-206. doi:10.1016/S0014-5793(97)00344-X

[31] Strzezek, J. (2002) Secretory activity of boar seminal vesicle glands. Reproductive Biology, 2, 243-266.

[32] Calvete, J.J., Mann, K., Schafer, W., Raida, M., Sanz, L. and Topferpetersen, E. (1995) Boar spermadhesin PSP-II: Location of posttranslational modifications, heterodimer 
formation with PSP-I glycoforms and effect of dimerization on the ligand-binding capabilities of the subunits. FEBS Letters, 365, 179-182. doi:10.1016/0014-5793(95)00452-F

[33] Manaskova, P., Liberda, J., Ticha, M. and Jonakova, V. (2002) Isolation of non-heparin-binding and heparinbinding proteins of boar prostate. Journal of Chromatography B-Analytical Technologies in the Biomedical and Life Sciences, 770, 137-143. doi:10.1016/S0378-4347(01)00480-7

[34] Basu, S. (2007) Novel cyclooxygenase-catalyzed bioactive prostaglandin F2 $\alpha$ from physiology to new principles in inflammation. Medicinal Research Reviews, 27, 435468. doi:10.1002/med.20098

[35] Serhan, C.N., Chiang, N. and Van Dyke, T.E. (2008) Resolving inflammation: Dual anti-inflammatory and proresolution lipid mediators. Nature Reviews Immunol- ogy, 8, 349-361. doi:10.1038/nri2294

[36] Taylor, U., Zerbe, H., Seyfert, H.M., Rath, D., Baulain, U., Langner, K.F.A. and Schuberth, H.J. (2009) Porcine spermatozoa inhibit post-breeding cytokine induction in uterine epithelial cells in vivo. Animal Reproduction Science, 115, 279-289. doi:10.1016/j.anireprosci.2008.11.019

[37] Aloe, S., Weber, F., Behr, B., Sauter-Louis, C. and Zerbe, H. (2012) Modulatory effects of bovine seminal plasma on uterine inflammatory processes. Reproduction in Domestic Animals, 47, 12-19. doi:10.1111/j.1439-0531.2011.01792.x

[38] Hansen, C., Madej, M. and Madej, A. (2013) Profile of seminal plasma proteins in relation to boars fertility-A pilot study. Program and Abstract Book, 9th International Conference on Pig Reproduction in Olsztyn, Poland, 9-12 June 2013, 149.

[39] Kaczmarek, M.M., Krawczynski, K. and Filant, J. (2013) Seminal plasma affects prostaglandin synthesis and angiogenesis in the porcine uterus. Biology of Reproduction, 88, 72 .

[40] Li, J.C., Yamaguchi, S. and Funahashi, H. (2012) Boar seminal plasma or hen's egg yolk decrease the in-vitro chemotactic and phagocytotic activities of neutrophils when co-incubated with boar or bull sperm. Theriogeno$\log y, 77,73-80$. doi:10.1016/j.theriogenology.2011.07.018

[41] Caballero, I., Parrilla, I., Almiñana, C., del Olmo, D., Roca, J., Martínez, E.A. and Vázquez, J.M. (2012) Seminal plasma proteins as modulators of the sperm function and their application in sperm biotechnologies. Reproduction in Domestic Animals, 47, 12-21. doi:10.1111/j.1439-0531.2012.02028.x
[42] Kimura, A. and Kishimoto, T. (2010) IL-6: Regulator of Treg/Th17 balance. European Journal of Immunology, 40, 1830-1835. doi:10.1002/eji.201040391

[43] Gutsche, S., von Wolff, M., Strowitzki, T. and Thaler, C.J. (2003) Seminal plasma induces mrna expression of IL-10, IL-6 and LIF in endometrial epithelial cells in vitro. $\mathrm{Mo}$ lecular Human Reproduction, 9, 785-791. doi:10.1093/molehr/gag095

[44] Von Wolff, M., Nowak, O., Pinheiro, R.M. and Strowitzki, T. (2007) Seminal plasma-Immunomodulatory potential in men with normal and abnormal sperm count. European Journal of Obstetrics Gynecology and Reproductive Bio$\log y$, 134, 73-78. doi:10.1016/j.ejogrb.2007.01.009

[45] Østrup, E., Bauersachs, S., Blum, H., Wolf, E. and Hyttel, P. (2010) Differential endometrial gene expression in pregnant and nonpregnant sows. Biology of Reproduction, 83, 277-285. doi:10.1095/biolreprod.109.082321

[46] Bersinger, N., Günthert, A., McKinnon, B., Johann, S. and Mueller, M. (2011) Dose-response effect of interleukin (IL)-1 $\beta$, tumour necrosis factor (TNF)- $\alpha$, and interferon- $\gamma$ on the in vitro production of epithelial neutrophil activating peptide-78 (ENA-78), IL-8, and IL-6 by human endometrial stromal cells. Archives of Gynecology and Obstetrics, 283, 1291-1296. doi:10.1007/s00404-010-1520-3

[47] Lee, H.Y., Acosta, T.J., Tanikawa, M., Sakumoto, R., Komiyama, J., Tasaki, Y., Piskula, M., Skarzynski, D.J., Tetsuka, M. and Okuda, K. (2007) The role of glucocorticoid in the regulation of prostaglandin biosynthesis in non-pregnant bovine endometrium. Journal of Endocrinology, 193, 127-135. doi:10.1677/joe.1.06975

[48] Einspanier, R., Krause, I., Calvete, J.J., Töfper-Petersen, E., Klostermeyer, H. and Karg, H. (1994) Bovine seminal plasma ASFP: Localization of disulfide bridges and detection of three different isoelectric forms. FEBS Letters, 344, 61-64. doi:10.1016/0014-5793(94)00362-9

[49] Reinert, M., Calvete, J.J., Sanz, L., Mann, K. and TöpferPetersen, E. (1996) Primary structure of stallion seminal plasma protein HSP-7, a zona-pellucida-binding protein of the spermadhesin family. European Journal of Biochemistry, 242, 636-640. doi:10.1111/j.1432-1033.1996.0636r.x

[50] Lusignan, M.F., Bergeron, A., Crete, M.H., Lazure, C. and Manjunath, P. (2007) Induction of epididymal boar sperm capacitation by $\mathrm{pB} 1$ and BSP-A1/-A2 proteins, members of the BSP protein family. Biology of Reproduction, 76, 424-432. doi:10.1095/biolreprod.106.055624 